DOI 10.15826/qr.2020.2.478

УДК 791(47:57)

\title{
THE “EROTIC” TRACTOR IN THE SOVIET CINEMA*
}

\author{
Rina Lapidus \\ Bar-Ilan University, \\ Ramat-Gan, Israel
}

Between the 1930s and the 1960s, much emphasis was put in the Soviet Union on the technological development of the country. One of the latest wonders of technology was the tractor, which harvested crops efficiently and rapidly. This article is concerned with the Soviet cinematic representation of work with tractors as the most erotic characteristic of a man. A man attractive to women in Soviet cinema is not handsome but rather is someone proficient in operating a tractor. On the other hand, a man who does not know how to operate a tractor is represented as impotent and is ridiculed by female characters. Several romantic films were produced in which the relationship between the protagonists developed against a background of the use of a tractor. These films became iconic and classic: everyone saw them many times and knew their scripts by heart. Most of the films depict a young Soviet man and his path to the heart of his girlfriend, and some show the maturation of the young character and his transformation into a real man. These goals are achieved through his work as a tractor driver. Examples of this are films like The Rich Bride (romantic comedy, 1937), Tractor Drivers (romantic drama, 1939), Cossacks of the Kuban (romantic comedy, 1949), It Happened in Penkovo (romantic drama, 1957), and Knight's Move (comedy, 1962). In all these films, work with tractors is represented as an integral part of the "machismo" of the Soviet man.

Keywords: Soviet cinema; image of a tractor driver; eroticism; masculinity.

В Советском Союзе с 1930-х по 1960-е гг. большое внимание уделялось технологическому развитию страны. Одним из последних чудес техники того времени был трактор, работа на котором позволяла эффективно и быстро обрабатывать поля. Статья посвящена советскому пропагандистскому представлению работы на тракторе как самой эротической составляющей маскулинности в советском кино. Мужчина, привлекательный для женщин в советском кино, был не красавцем, а человеком, который умел управлять трактором. С другой стороны, если он не умел управлять трактором, он был представлен как импотент и подвергался осмеянию героями фильма, особенно женщинами. Был выпущен ряд

* Citation: Lapidus, R. (2020). The "Erotic" Tractor in the Soviet Cinema. In Quaestio Rossica. Vol. 8, № 2. P. 519-535. DOI 10.15826/qr.2020.2.478.

Цитирование: Lapidus R. The "Erotic" Tractor in the Soviet Cinema // Quaestio Rossica. Vol. 8. 2020. № 2. P. 519-535. DOI 10.15826/qr.2020.2.478.

(C) Lapidus R., 2020

Quaestio Rossica • Vol. 8 • 2020 • № 2, p. 519-535 
романтических фильмов, в которых отношения между героями развивались в соответствии с умением мужчины управлять трактором. Они стали культовыми, классическими: все видели их много раз и знали их сценарии наизусть. Большинство фильмов изображало молодого советского героя и его путь к сердцу подруги, а некоторые показывали его возмужание и превращение в настоящего мужчину. Эти цели достигались благодаря работе героя на тракторе. Примерами таких кинокартин были «Богатая невеста» (романтическая комедия, 1937), «Трактористы» (романтическая драма, 1939), «Кубанские казаки» (романтическая комедия, 1949), «Дело было в Пенькове» (романтическая драма, 1957) и «Ход конем» (комедия, 1962). Во всех них умение управлять трактором представлялось как важнейшая характеристика советского мужчины.

Ключевые слова: советское кино; образ тракториста; эротика; маскулинность.

\section{Introduction: A Tractor as an Indicator of the Erotic Potential of Soviet Man}

This innovative article is concerned with an interesting aspect of Soviet mass media, namely, political propaganda by means of the erotization of agricultural labor in cinema [see: Cody]. Thus, a man attractive to women in Soviet literature and cinema is not handsome but rather is someone proficient in agricultural labor and operating a tractor in particular, the latest technological achievement in the 1920s and 1930s [Соцреалистический канон]. On the other hand, a man who does not know how to operate a tractor is represented as impotent and is ridiculed by the beautiful female characters. The idea of work with a tractor as an element of a man's emotional and erotic capabilities was most clearly manifested in Soviet cinema from the 1930s to the end of the 1960s.

\section{The Symbolization and Erotization of the Tractor in Soviet Cinema}

Various objects and actions may be given symbolic meanings in culture, including an erotic meaning. The erotization of various objects and actions is widely used in the arts and cinema. This symbolization makes the work more interesting and attractive. Soviet propaganda gave erotic meaning to the tractor, a working implement, in order to draw the people's attention to this new agricultural machine and arouse their interest in it [see: Cirlot].

In literature, we find phallic symbolism based not on imitation of the external form and action of the male sexual organ, but on its function. When the heroine of a work prefers to use an object rather than to engage in a sexual act with a man, this object is given an erotic, sexual meaning based on the functions it performs for the heroine. When a woman gains 
more pleasure in using an object than in having sex with her husband, this object, regardless of its form, becomes the husband's competitor. We have an example in Yury Polyakov's novel Kostya Gumankov's Paris Love. The main character, Kostya Gumankov, cannot wait for his wife to come to his bed. But, to his great regret, she prefers to talk with her female friends on the phone. Kostya, insulted, notes with bitterness that if phones receivers were made in "a certain shape", meaning the shape of a phallus, women would completely forsake men. He adds that even now, when the receiver does not have "the necessary shape", it is still more attractive for his wife than he is [Lapidus, p. 125-126].

During intensive industrialization in the young Soviet state, erotic meanings and symbolisms were given to various tools and machines depicted in cinema in order to draw the attention of workers to these matters. These erotic meanings and symbolisms were invented by Soviet propaganda and had no cultural roots. Tools and machines were far from possessing an external phallic form and in no way resembled anything erotic, but they were given an erotic significance by communist ideological propaganda.

In the Soviet Union from the 1930s to the 1950s, much emphasis was laid on the country's technological development, previously a backward agricultural land. Agriculture, the country's chief source of revenue, was primitive, slow, and inefficient. The farmers worked the land with a plow harnessed to horses or oxen, as they had for hundreds of years, and they harvested their crops by hand. Needless to say, this hindered output, which was a crucial matter in view of the starvation which existed in the Soviet Union during that period [Lerman, Kislev, Biton]. Agricultural technology was therefore a primary concern and was promoted by the media and by Soviet propaganda. One of the wonders of technology was the tractor, which harvested crops efficiently and rapidly [Rezun].

In this period, the authorities invested heavily in the development of the cinema, which was an important propaganda instrument for the masses. The cinema was also a prestigious achievement in an international arena looking with curiosity at the first communist state in the world. The cinema transmitted propaganda messages for the promotion of agricultural technology. The tractor was represented in films as a sort of "king of agriculture" on whom the future of the country and the wellbeing of the people depended. A number of romantic films were produced in which the relationship between the main protagonists developed against the background of the use of a tractor. These films became iconic, classic: everyone saw them many times and knew their scripts by heart. Sayings from these films became proverbs. These films contained many episodes, but there were also elements of repetition [Benjamin]. All the films without exception presented a young Soviet man, full of strength, who saw his future optimistically. The great majority of the films are romantic and depict the main character's circuitous path to the heart of his girlfriend and their final happy marriage, while some of the films show 
the maturation of the young man and his transformation into a real man. All the films have a strong element of "machismo" and present a teaching example of the true Soviet man [Ellul].

In order to promote physical labor, the tractor is presented not as an agricultural machine, but as evidence of the tractor driver's masculinity. When a tractor driver operates his machine with skill, all the girls of the village, and especially the village beauty, appreciate it and show him respect, with an obvious hint that their relations will continue in the personal realm. On the other hand, when a tractor driver cannot cope with his task, the women and girls show him contempt, and the beauty of the village, with whom he is in love, does not even want to look at him, which causes panic and desperation on his part. He is eager to correct this situation, much like a man who discovers he is impotent in an intimate situation. In all the films there is something to which one pays no attention at first, but which prove to be the decisive factor: the tractor.

The protagonist's girlfriend is only ready to open her heart when he shows that he has full mastery of the tractor. In some cases, the romantic love between the protagonist and his girlfriend develops against the background of agricultural work with the tractor. In the same way, a Soviet youth can only become a man to whom women react positively if he gains full mastery of this vehicle.

The protagonist of Soviet cinema can only realize his virility through the use of agricultural technology and the tractor in particular. On the other hand, the man who cannot use agricultural technology is depicted in the Soviet cinema as lacking in virility and impotent. He is also regarded as having no value for Soviet society at large. The defining identity of the protagonist of Soviet cinema is established by his skills in the use of agricultural technology and especially the tractor.

Moreover, in all these films there is no depiction of sexual relations between the protagonist and his girlfriend, but his attitude to his tractor suggests his potential relationship with the woman he loves and desires. For example, the protagonist is excited and attracted when he is about to work with the tractor. When he does not succeed in operating the machine, he is seized with panic and is completely at a loss. He is like a man who suffers temporary impotence in intimate relations with his partner. On the other hand, when he finally succeeds in operating the tractor, he is ecstatic, pleased with himself, and celebrates his success. When he has finished working successfully with the tractor, he is relaxed and satisfied: those around him, and Soviet society in general, welcome him enthusiastically as a great success and a true hero [Fitzpatrich].

\section{The Rich Bride - musical comedy, 1937}

The film begins with a depiction of the harvesting season in a Ukrainian kolkhoz ${ }^{1}$. There is a song about harvesting. There is later a song about

\footnotetext{
${ }^{1}$ The lyrical comedy The Rich Bride was released in 1937, directed by Ivan Pyryev.
} 
tractors, which became very popular in the Soviet Union. The viewers see a chain of tractors going to work.

Young Komsomol members are engaged in harvesting. There is also a women's agriculture unit working in the field; they are tying the sheaves mowed by the tractors. A song is heard encouraging women to work: ' $\mathrm{Hi}$ girls, hi beauties! Let our Motherland sing songs about us!' ${ }^{2}$ which is probably the most famous song about young Russian women. The tractor driver Pavlo and a girl from the kolkhoz, Marina, are in love and wish to get married. But the accountant of the kolkhoz, Kovinko, has long been in love with Marina, too, and is plotting various ways of interfering in the relationship. Kovinko is jealous of Pavlo and wants to become a tractor driver just like him.

Late in the evening, after a hard day of harvesting, the young people start to dance. Afterwards, young couples start leaving the dancehall and hide, kissing and hugging, in every corner of the kolkhoz. Marina's grandfather is the kolkhoz's watchman and he sees the hiding couples. He urges them to go home and to bed, declaring that the next day is another day of harvesting, and harvesting is as important as winning the war against the Nazis. Suddenly he notices that Marina and Pavlo are one of the couples. The grandfather is pleased with his granddaughter's choice and spreads the news that Marina and Pavlo are about to get married. But Kovinko is out of his mind with jealousy and decides to thwart the wedding.

The next morning, all the young people are working in the fields again. The working people call the tractors "iron horses", as tractors are highly cherished and appreciated. The working unit of girls initiates a competition with the men: who can mow faster? Both teams are urged to mow faster and faster. Pavlo is operating a tractor but it breaks down. Pavlo is absolutely heartbroken. The working people around him laugh and make fun of him. Finally, he fixes the tractor alone: everyone around him appreciates and honors him. The girls look up to him with admiration. Pavlo boasts that he is capable not only of fixing a tractor single-handedly but also a tank and war plane. No one can compare to Pavlo. In this film, we see that the romantic relationship between the protagonist Pavlo and his girlfriend Marina depends on his skills in operating a tractor. His relationship to his tractor suggests his potential relationship with the woman he loves.

Kovinko designs a plot intended to foment a quarrel between Pavlo and Marina. Thus, he shows Pavlo false documents in which Marina is declared lazy and has earned only a small number of "workdays" ${ }^{3}$. He also shows similar documents to Marina, falsely testifying that Pavlo is lazy and poor.

Marina is upset, but, to her great surprise, she sees that the chairman of

2 Lyrics by Vasily Lebedev-Kumach (1898-1949), music by Isaak Dunayevsky (1900 - 1955). Lebedev-Kumach was a Soviet poet and lyricist, widely known for his patriotic songs in the Stalin era. Isaak Dunayevsky was a Soviet film composer and conductor of the 1930s and 1940s. He is considered one of the greatest Soviet composers of all time.

${ }^{3}$ A workday is trudoden in Russian and it literally means "a day of labor". It was a unit of value and a means of assessing the quantity and quality of labor as a factor of production in kolkhozes in the Soviet Union from 1930 to 1966. It was also a form of payment. 
the kolkhoz praises Pavlo as the best worker. On the other hand, Pavlo is also upset because he is unaware that Kovinko has deceived him concerning the laziness of Marina. But as a true Soviet man, he declares that he loves Marina and it is not important to him how many "workdays" she has earned. Finally, it turns out that Marina has a lot of "workdays": she is a rich bride in terms of the kolkhoz. Pavlo and Marina make up. After the harvesting is over, there is a party and everyone dances. The film has a happy ending.

This film is the first in the series of Stalin's propaganda films promoting agricultural work with tractors. It is a merry film, full of energy and lively music; it immediately became popular throughout the country. The year 1937, besides being the year of the greatest and cruelest of Stalin's acts of terror, was also a year of mechanization in Soviet agriculture, industry, and the army. People associated with technology came to the fore. In kolkhozes, the most appreciated machine was the tractor.

In this film, the tractor is given primary importance in every way. The tractor is not only an agricultural machine that ensured physical survival and protection from starvation but is also an integral part of the life of every person in the village. It is the object of the hopes of every member of the kolkhoz. They look upon it as a kind of higher authority, a sort of totem that has the power to defend the citizens against all afflictions and all potential enemies. The happiness of the Soviet citizen depends entirely on the tractor [Соцреалистический канон].

The film contains a famous song about the tractor which became a folksong among generations of Soviet citizens ${ }^{4}$. The March of Tractor Drivers goes as follows:

\section{The March of Tractor Drivers}

Ой вы, кони, вы кони стальные,

Боевые друзья - трактора.

$<\ldots>$

Наша поступь тверда,

И врагу никогда

Не гулять по республикам нашим!

$<\ldots>$

Ой вы, кони, могучие кони,

Ой вы, кони, стальные бока,

Мы за счастьем поедем в погоню,

Мы любого осилим врага!
Oh, you horses of steel,

You battle friends-tractors.

$<\ldots>$

Our tread is solid

And the enemy will never

Walk in our republics!

$<\ldots>$

Oh you, horses, mighty horses,

Oh, you horses with steel sides, We will go in pursuit of happiness We will defeat any enemy!

The song begins by relating to the tractor as a tool for working the land at harvest-time but ends by celebrating it as a higher authority defending the beloved motherland from enemies seeking to conquer and destroy it. In these songs and films, the tractor appears as a means of support for the Soviet citizen, who becomes a soldier in a battlefield, whether it

\footnotetext{
${ }^{4}$ Music by Isaak Dunayevsky, lyrics by Vasily Lebedev-Kumach.
} 
is the battlefield of agricultural labor or the battlefield for the defense of the Soviet Union.

The Soviet man becomes a servant of the tractor or of any other technological tool used in agriculture, industry, or warfare. It is the duty of the Soviet man to devote his life to operating heavy technological mechanisms: tractors, combine harvesters, trucks, tanks, airplanes. He is judged by the work he performed using these mechanisms, and his personal qualities are unimportant and not taken into account. The image of the Soviet man in these songs and films is standardized and life in the Soviet Union depicted as good, optimistic, and joyful. The citizens of the Soviet Union are represented in a positive light, as full of confidence and happy, but the reality was quite the opposite. For instance, one of the actors in the film, Semyon Shagaida ${ }^{5}$, who played the comic figure of the barbermusician, was arrested by the Stalinist authorities as soon as work on the film ended and was shot immediately after his arrest.

\section{Musical drama Tractor Drivers ${ }^{6}$}

Three demobilized tank drivers ride a train from the front back to their villages. Each of them praises his home kolkhoz. One of them, Klim, is going to Ukraine, to see Mariana, a girl whom he has never met; however, he has seen her portrait in a newspaper and made contact with her. She is a brigadier of a team of tractor drivers. After the publication of her portrait in the newspaper, she receives lots of letters every day, including many from admirers who propose marriage to her. Many also come to her kolkhoz in order to personally propose to her.

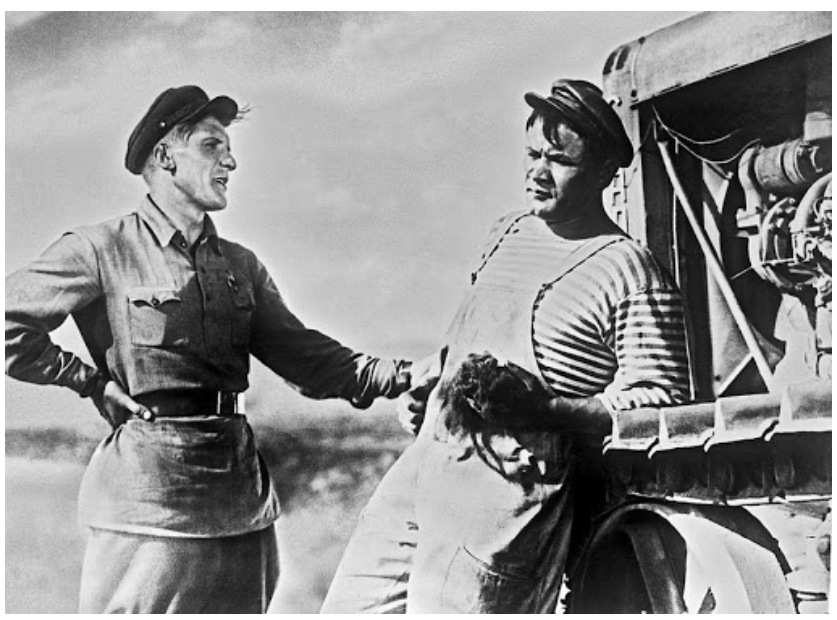

Scene from Tractor Drivers. Nikolai Kryuchkov as Klim Yarko (left) and Boris Andreyev as Nazar Duma Mariana jokingly asks the chairman of a team of tractor drivers, Nazar - a very large and strong man - to pretend to be her fiancé in order to fend off annoying admirers.

\footnotetext{
${ }^{5}$ Semyon Shagaida (1896-1938), a Ukrainian and Russian actor, arrested and charged of being a Ukrainian nationalist, was executed promptly after arrest.

${ }^{6}$ Musical drama Tractor-Drivers was released in 1939, directed by Ivan Pyryev.
} 


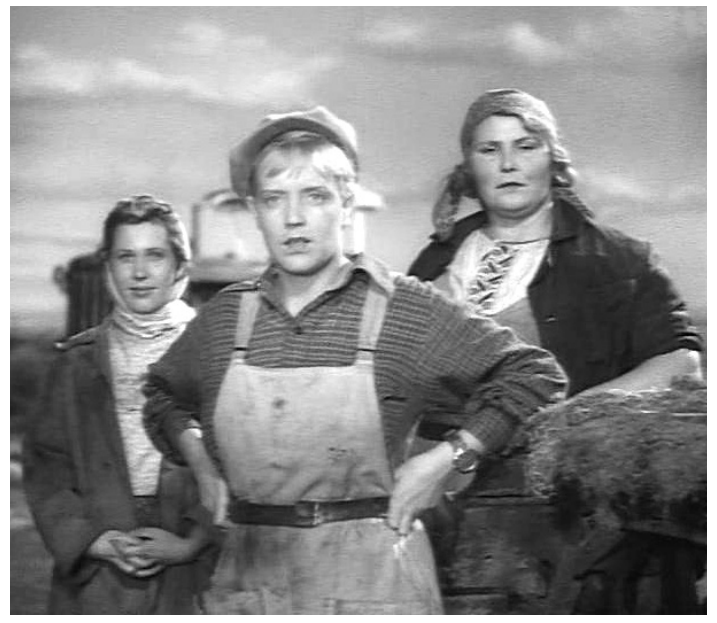

Scene from Tractor Drivers.

Marina Ladynina as Maryana Bazhan, in the center

The collective farm chairman, Kirill Petrovich, a person lacking in a sense of humor, does not understand that Mariana is kidding. He takes Mariana's offer to Nazar seriously and disapproves of Mariana's choice, as Nazar is lazy and a bad tractor driver. All these scenes unfold against the background of Isaak Dunayevsky's songs "Harvest, our harvest, is high harvest" and "Oh, you tractors are steel horses".

When night comes, a storm is brewing. The kolkhoz workers sing the song "Harness horses, boys" and ride the tractors home. Mariana gets on a motorcycle and rushes home through a field. On the way, she crashes into a dune and falls, hurting her foot. At this time, a kolkhoz member, Klim, passes by Mariana and sees that she has had a motorcycle accident. He sees that Mariana has fallen and injured her leg. He carries Mariana to her home and tries to treat her leg. Later, he also repairs the tractor of Mariana's girlfriend, which was left next to Mariana's home. He is a good-looking man and plays the harmonica well. Klim fought in the Second World War as a tank driver, a fact which suggests that he is a man with high moral standards. He continually sings the song, "Three tank drivers, the team of a war machine, three devoted friends” («Три танкиста, три веселых друга, / Экипаж машины боевой»). He is the embodiment of a heroic male. Mariana offers him a job as a mechanic on the kolkhoz.

Klim begins to work. He has clashes with Nazar, who is lazy and does not take care of the kolkhoz property. Nazar decides to tease Klim and tells him that he is Mariana's fiancé and will not give her up in favor of Klim. Klim is angry and wants to leave for another collective farm. One day, Kirill Petrovich approaches Klim and asks him to become the brigadier of the tractor drivers' team instead of Nazar, who was caught stealing fuel. Klim agrees, but the team react with hostility. In response to a request to start work, they begin to dance. Nazar sits high on a tractor and grins. Klim shows his ability in dancing and work. Everyone recognizes his leadership and begins to change, even Nazar.

The team of tractor drivers headed by brigadier Klim becomes one of the best in the region. Klim suggests that the kolkhoz members should not only do outstanding work but also engage in military training. In the event

${ }^{7}$ Following the Ukrainian folksong "Guys, unharness horses and go to bed to rest..." («Распрягайте, хлопцы, коней / Да ложитесь почивать...»). 
of war, tractor drivers can become tank drivers and defend their beloved Soviet Motherland. The kolkhoz members by chance find a German helmet from the First World War and use it for shooting practice, which suggests the possibility of a pending war. Nazar admits that Klim is better. Nazar follows Klim and starts admiring tanks and singing songs about them. Mariana and Klim confess their mutual love and decide to get married. The movie has a happy ending. The wedding is held in a patriotic atmosphere, the guests sing the song "We don't need a foreign land, but we will not give Moscow away” («Чужой земли мы не хотим ни пяди, / Но и своей вершка не отдадим») and express their devotion to socialism.

This is the most famous film of the entire Stalin period. The main protagonist Klim is a tank driver in a group of Soviet troops that defeated Japanese troops in 1938. The protagonist represents the typical image of a glorious hero: he served as a tank driver in the victorious war, he serves as a tractor driver in the postwar era; he is an innovative mechanic-technician. He seems to be the perfect Soviet superhero.

Thanks to prominent actors who were convinced of the correctness and necessity of making such a film, it gained unprecedented popularity among the youth in the Soviet Union. Hundreds of thousands of young people seeking to resemble Klim went to work in collective farms as tractor drivers. The protagonist Klim was depicted in a way that became incredibly popular among women throughout the Soviet Union.

Proficiency in operating a tractor is shown in this film as the most important quality and skill in a man's life. It characterizes the man as a most admirable person in all respects in the eyes of those around him. Proficiency in operating a tractor makes him complete. On the other hand, someone who does not know how to operate a tractor finally understands that he has no option other than to gain this proficiency as quickly as possible; otherwise, he will lose his place in Soviet society, will fail to build a family, and will remain isolated, without a livelihood and without a future. The tractor is the sole and absolute criterion that everyone bows down to. The tractor was a kind of god of Soviet agriculture from 1930 to 1960.

\section{Musical comedy Cossacks of the Kuban ${ }^{8}$}

Galina Ermolaevna, who is chairman of a kolkhoz, rides in a cart to a fair. She meets Gordei Gordeevich, who is chairman of a nearby collective farm and also riding to the fair. Their kolkhozes are in socialist competition for greater productivity. Galina and Gordei secretly love each other, but they do not confess this. Galina has been a widow for the last seven years, and Gordei Gordeevich has loved her all his life, even before she got married. Each of them feels they are involved in a clash of interests. Both feel they cannot realize their love because they are chairs of competing neighboring kolkhozes, and to unite as a loving couple would be a betrayal of their socialist duty.

\footnotetext{
${ }^{8}$ The musical comedy Cossacks of the Kuban was released in 1949, directed by Ivan Pyryev, script by Nikolay Pogodin.
} 


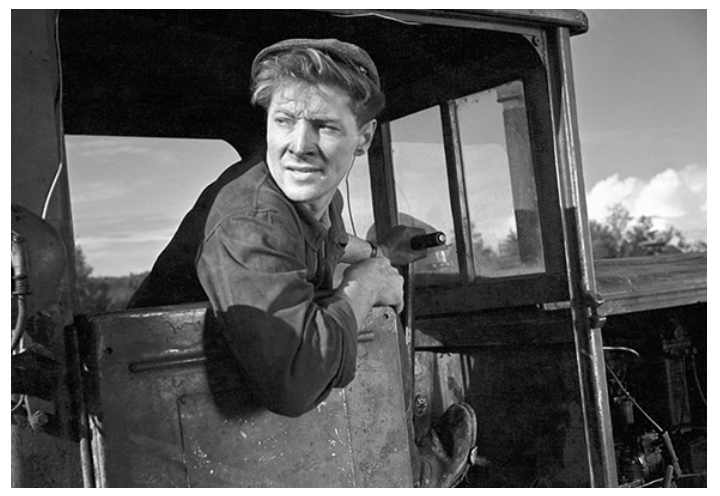

Scene from It Happened in Penkovo. Vyacheslav Tikhonov as Matvey Morozov
Finally, each of them arrives at the fair. There is a great abundance of products, commodities, and manufactured goods. There is even a Moskvitch, a Soviet car, for sale there. Since there is a plethora of goods, Galina's kolkhoz has to reduce its prices by 20 percent. Gordei's kolkhoz is compelled to reduce its prices by 30 percent, although both kolkhozes initially planned to raise

their prices. The fair is full of young people walking around and choosing whatever they want to purchase for themselves.

This is a propaganda scene, intended to demonstrate to the Soviet people, constantly suffering from shortages in all spheres of life, how wonderful and rich their lives would be if socialism were achieved. Kolkhozes are shown to be reducing their prices by tens of percent. The presence of many young people in the market is intended to "prove" that they are satisfied in the countryside and have no wish to leave for large cities.

It is emphasized in the film that people not only work hard in the kolkhoz but also enjoy a high level of cultural activities. Thus, Galina and Gordei meet by chance in the regional store for musical instruments. Galina purchases a piano for the amateur club in her kolkhoz. People who come to the store with Gordei ask him to purchase a piano too, but he is reluctant at first as it is expensive. In the end he feels compelled to purchase one since Galina's kolkhoz and his own are competing with one another and he cannot afford to lose.

There are a lot of amateur artistic events in the kolkhoz such as dances and singing in the kolkhoz choir. In one of these events, in the evening in the main hall of the kolkhoz, members sing romantic songs as a hint to Galina and Gordei. Then there are dances, and young men from Galina's kolkhoz court girls from other kolkhozes, including Gordei's. The festival continues for the next few days, with the appearance of an amateur kolkhoz circus, equestrian competitions, and plenty of food and drink. Gordei's adopted daughter falls in love with a guy from Galina's kolkhoz. Gordei objects to their relationship as he is afraid that if they get married, his adopted daughter will leave for the kolkhoz of her husband, depriving his own kolkhoz of an industrious young worker.

The turning point of the plot is an equestrian competition. In the decisive final race, the winner is the young man who loves Gordei's adopted daughter. Gordei now consents to their marriage. In the doubles race, the competitors are Galina and Gordei. It is not clear until the very 
end who the winner is, but Gordei finally emerges victorious. Someone in the viewing public sarcastically suggests that Galina faltered in the last dash in order to let Gordei win and so flatter him. After the competition, Galina secretly reveals to a friend that she loves Gordei, and the friend informs Gordei of that fact.

At the end of the film, Galina and Gordei get married, along with Gordei's adopted daughter and her beau. All of them go back to their kolkhozes singing patriotic songs about the dear Soviet motherland. The viewing public sees the prosperity of each of the kolkhozes, which were also equipped with wonderful technical machines like tractors.

This was the last film of the Stalin epoch and has much in common with the The Rich Bride (see above). Both were directed in the style of operetta, supported by the brilliant music of Dunayevsky. Both present Soviet reality in a utopian, saccharine light. The main difference between the protagonists of this film and The Rich Bride is their age. While the characters in The Rich Bride are young people, those in the later film are "adults". Galina and Gordei are shown as successful leaders of advanced kolkhozes. They have much to teach the young and show themselves to be caring mentors. It is said that after watching the film, Stalin commented that agriculture in the country was good. In fact, in 1949, when the film was made, the situation in the country was extremely difficult and even desperate.

Nevertheless, both films always remained very popular, even though the abundance and joyful reality shown in them never arrived. It is thought that the reason for their success is that they represent a cheerful musical fairytale where all the characters are fairytale characters, with their intelligence, beauty, strength, and wisdom. The negative characters only set off the beauty and moral excellence of the protagonists.

The film shows that socialist competition for greater productivity between different kolkhozes leads to the prosperity of Soviet citizens and encourages successful love among couples of all ages, both older couples (like Galina and Gordei) and young people (like Gordei's adopted daughter and her darling). It is socialist competition that leads to the marriage of these two couples. Socialist competition both helps the beloved Soviet motherland economically and allows individuals to find personal happiness. Tractors have a marginal role in this film. They are part of the future happiness of the Soviet people for which individuals like Galina and Gordei are constantly toiling.

\section{Romantic drama It Happened in Penkovo ${ }^{9}$}

The film begins with a description of the protagonist Matvey riding a train back to his home kolkhoz after serving a term in a prison. He makes friends with the train conductor and tells him his story and how he was sentenced.

${ }^{9}$ The romantic drama It Happened in Penkovo was released in 1957, director: Stanislav Rostotzkii, script: Stanislav Rostotzkii, Sergei Antonov. 
Matvey was a tractor driver in his home kolkhoz. Once a lecture was given in the kolkhoz club, but Matvey and the daughter of the kolkhoz chairman left and spent time together in a quiet corner of one of the streets. The chairman saw them kissing and got mad, as Matvey had the reputation of being a good tractor driver but not a moral person. When Matvey proves he is serious about the girl, he proposes to her and she happily accepts. They set a date for a wedding.

Before the wedding, Matvey returns in a cart from the station. A young lady, Tonya, is also riding in the cart. She is a veterinarian, newly graduated from a university in Leningrad, and is returning to her kolkhoz to start her career there. She is to temporarily stay with her grandfather as she has no parents. Her grandfather disapproves of Matvey, and speaks of his disgraceful behavior, his drinking, and his damage to life in the kolkhoz. Tonya at first dislikes life in the kolkhoz, especially the treatment of livestock there.

A correspondent from a paper in the big city arrives to write an article about an outstanding worker, Zefirkin, and photograph him. Matvey is jealous and attempts to prove that he is an even better worker, but in vain. He comes up with a suggestion for a competition: to see whose tractor is stronger, the vehicles are attached to a trailer and pull in different directions. Matvey's tractor breaks down. Harming and destroying kolkhoz property is a felony: an investigator arrives and talks with Matvey. He finds out that the main suspect, Matvey, and the daughter of the chairman of kolkhoz secretly registered their marriage. The case is dropped and they now celebrate the wedding.

The competition is motivated by Matvey's jealousy of Zefirkin, the most successful and admired man on the kolkhoz. The tractor is used by Matvey to show that he is the real success story and it is he who should be admired and photographed for the newspaper. He wants to use the tractor for selfish, frivolous, immoral, and illegal purposes. But the tractor breaks and gives rise to a crisis in Matvey's heart as well, for he understands the seriousness of his actions and internalizes the fact that his behavior was not only not moral but illegal.

Matvey, who fought in a tank in the Second World War, is essentially a man of high morals. In the war, he had shown himself to be honest, brave, and loyal. His desire to throw off all restraint that one sees at the beginning of the film disappears at the shocking sight of the broken tractor, and he admits his fault. After this incident, he becomes himself again: a noble person who works honestly in the spirit of a true Soviet citizen.

Later, Matvey and Tonya get to know one another better and begin to like each other. Matvey drives Tonya home in his tractor. A female neighbor spreads rumors about them. Matvey's wife gets very jealous. In the kolkhoz, they start building a club on Tonya and Matvey's initiative. They are both eager to advance the construction, and one night they meet there by chance. They confess their mutual affection, but Tonya is very reluctant and does not encourage Matvey to take further action. They never consummate their mutual love.

At the end of their casual encounter, Tonya stumbles and injures her leg. Matvey brings her home in his arms. A female neighbor sees it and informs Larissa, Matvey's wife, that Matvey and Tonya are lovers. She 
persuades Matvey's wife to poison Tonya. Matvey's wife pours poison into a cup of tea she gives to Tonya, but at the last moment realizes that Matvey did not actually betray her with Tonya and knocks the cup out of her rival's hands. Larissa tells Matvey that the neighbor had told her that he and Tonya were lovers. He runs to the neighbor in a rage, hits her, and locks her in a cellar. Consequently, Matvey is charged in court with violence. As a noble person, he admits to being guilty and forbids his wife from giving testimony mentioning Tonya's name in order to avoid evil rumors about her. He is sentenced to serve two years in prison for violence. Now he comes back from prison (the beginning of the film). At home, he sees his infant son, who was born in his absence, for the first time. He decides to remain with his family. When he meets Tonya by chance, they exchange glances in a friendly way.

This film was a breakthrough in its humanization of Soviet people and its focus on the fate of ordinary people. The characters in the film have strong emotions and are torn apart by their hesitations, their impulses, and their suffering. In this film, work with a tractor is less felt and there is more emphasis on the hard fate of women such as Tonya who remained alone after the Second World War. But the breakdown of the tractor in the competition is a crisis point in Matvey's life. Before the competition, Matvey feels that he deserves compensation for his years of fighting in the war, even if that compensation is at the expense of public property belonging to the kolkhoz. But after the incident with the tractor, his conscience is aroused, and he understands that one has to act morally towards everyone, including those who did not fight in the war. He understands his feeling, that he deserves more than others because he suffered for five years in the war and endangered his life, is not right or justified.

In this film, the tractor appears as a thing of great value - something sacred. And therefore, when Matvey breaks the tractor in the competition, this is seen as crossing every human, moral, and sacrosanct boundary. At the same time, Matvey works as a tractor driver on a kolkhoz, and this shows him as a man of a high moral standards. In this film, as in others of this period, the tractor is seen as having a supreme value.

\section{Comedy Knight's Move ${ }^{10}$}

Knight's Move is a Soviet feature film made in 1962, based on a young people's novel by Mikhail Zhestev ${ }^{11}$, The Adventures of a Little Tractor Operator (1957). Fifteen-year-old Alyosha Levshin, who dreams of becoming a high-class tractor driver, is not allowed to work on the collective farm because he is too young. Then he exchanges his documents with his elder comrade, Kolka Lopatin, who dreams of a carefree life in the city. As a result, Alyosha gets an honors diploma, but he still cannot work

\footnotetext{
${ }^{10}$ The comedy Knight's Move was released in 1962, director: Tatiana Lukashevitz.

${ }^{11}$ Mikhail Zhestev (real name Mark Ilich Levinson, 1902-1983) was a Soviet and Russian novelist, essayist, and journalist.
} 
on a collective farm because of his young age, and he is assigned to work in his home school as an assistant of the teacher.

There is a class in the school and all the students read the novel $M y$ Apprenticeship by Maxim Gorky, where the author describes the crucial importance of serious work in one's life. The protagonist Alyosha reads a book about tractors. After school, Alyosha and his friend Kolka go to see tractors at work. Kolka is an assistant to a tractor driver, but he does not enjoy working with the tractors and is very lazy.

Shugai is the manager of all the tractor drivers and operates a tractor masterfully: he brings down a huge tree that the others could not fell. Shugai is impressed by Alyosha's interest in tractors and promises to teach him how to operate a tractor when he grows up. Shugai leaves his work and goes for a break. Alyosha climbs onto his tractor and starts driving. He notes that people saw him stealing a tractor for a drive. He gets frightened and drives the tractor into a river. He hides under the walkways above the river. Everyone thinks he was drowned and begin to search for him with great commotion, but in vain. When his grandmother calls him, he comes out of hiding, feeling guilty and confused, as he failed to realize the panic he caused by his disappearance.

Kolka sees a luxurious Volga car in the big city and the young men sitting in it: they wear shirts, tight pants, and thick-soled shoes. These are urban bums, condemned by official Soviet media and the public but nevertheless very attractive for a frivolous lad like Kolka. They seem to behave like the spoiled children of big bosses. Kolka is jealous of them and dreams of such a life.

At this time, Alyosha's aunt appears on the stage. She is about to sell her house where she lives with her mother (Alyosha's grandmother) and Alyosha himself, as he has no parents. She intends to send her mother to her grownup daughter living in the city and Alyosha to her brother, Alyosha's uncle, who lives in another part of the city. Alyosha has never met this uncle.

Alesha is upset as he has to part with his home village and his dream of learning how to operate a tractor. At this time, Kolka (who is two years older) gets a referral from a collective farm to a tractor driver's school in the big city. Kolka is eager to leave for the city and enjoy life there, but he does not want to attend the tractor drivers' school. The opposite applies to Alyosha: his dream is to study in the tractor driver's school. They decided to exchange documents - Alyosha goes to the school as if he were Kolka, and Kolka heads to Alyosha's uncle, pretending to be his nephew.

In the city, it turns out that the manager of the dormitory in the school is Alyosha's uncle, but neither the manager of the dormitory nor Alyosha are aware of this. Nevertheless, they feel close to one another and become good friends as both of them are fond of tractors.

In the dormitory room where Alyosha is put, a new tenant appears: Pomerantsev, a cunning rogue who wants to cheat everyone. At one point, Alyosha teaches him to play chess and Pomerantsev likes the knight, because it can move two steps forward and one step aside, a metaphor for his lousy character. In the school, Alyosha is the best student and Pomerantsev ends up as the worst. However, Pomerantsev realizes that Alyosha is not the 
person he claims to be: he cannot return to his native village because his deception would be revealed.

Therefore, Pomerantsev suggests to Alyosha that he, Alyosha, should go to Pomerantsev's village, where Pomerantsev will arrange for Alyosha to be his assistant tractor driver. Alyosha accepts the offer and works brilliantly; soon, Pomerantsev goes to a nearby collective farm to call Shugai himself for a competition. Everyone feels that something is wrong, because Pomerantsev says he is working with Shugai's former assistant, Kolka, who was feckless and a loafer.

Meanwhile, Kolka matures and becomes more serious. Hence, people stop giving him the nickname "Kolka" and start calling him by his proper name, "Nikolay". He begins to realize the wrongness of his life. His big-city acquaintances extort money from him. He wants to escape from them in that fancy Volga car which initially attracted him to move to the city. But while driving the car, he crashes into a soda machine and covers the car with sweet syrup. He is detained by the police and all his wrongdoings, lies, and cunning are revealed. Nikolay is disappointed with life in the city and his own behavior; he is willing to reform his life and to become a moral, decent Soviet citizen.

Shugai is very happy about Alyosha. His grandma returns to the kolkhoz in the village. Nikolay is now willing to study at the school for tractor drivers. The film ends with Alyosha working with a tractor, and he begins to replace Shugai as a teacher in courses for tractor drivers in his native village.

This film is a merry comedy with a happy ending and the best comic actors in Soviet cinema. It is a comedy of changing positions and misunderstandings, very skillfully made. The tractor driver Shugai is Alyosha's ideal; he is also decorated with a medal of the Hero of Socialist Labor, the highest award for working people in the Soviet Union. His appearance is masculine and handsome, and his behavior resembles that of pilots. At the same time, he is a figure from the films of the 1930s and 1940s about tractor drivers. Urban youth are shown as parasites, semi-criminals, living on the edge, wasting their parents' money or engaged in theft. City life, opposed to peasants' life in rural villages, is shown as defective. A person who admires big city life is depicted as an admirer of Western culture, a semi-traitor of the dear Soviet Motherland.

But if we compare this film to It Happened in Penkovo (see above), we may note that there is significant socialist propaganda in this film. Thus, the young viewing audience is brainwashed to prefer agricultural work with a tractor on a kolkhoz to all the benefits of a carefree life in a big city. The film urges them to devote their lives to building communism. These were the years of the creation of the Moral Code of the Builder of Communism ${ }^{12}$ and its spread

${ }^{12}$ The Moral Code of the Builder of Communism was a set of principles of communist morality, included in the texts of the third program of the CPSU and Articles of the Communist Party of the Soviet Union adopted by the 22nd Congress. These principles included devotion to the cause of communism, to the socialist Soviet Motherland and to all socialist countries, honest labor for the good of the public as a whole, awareness of socialist public duties, intolerance of individuals who disregarded public interests, intolerance of enemies of communism, etc. 
throughout the Soviet Union, with the task of achieving communism by 1980. The film was released in 1962, a year after Yuri Gagarin's space flight ${ }^{13}$, when young men in the Soviet Union were dreaming of becoming pilots. Young people were leaving rural areas in droves. The film was intended to arrest this tendency and to attract them to the challenges in the rural villages, which could bring them honor and satisfaction. At the same time, this was the famous generation of the sixties, from which emerged the poets Yevtushenko $^{14}$, Akhmadullina ${ }^{15}$, and Voznesensky ${ }^{16}$, the artists Shemyakin ${ }^{17}$ and Neizvestny ${ }^{18}$, anti-Soviet dissident writers, and many people who determined Russia's path in the late twentieth and early twenty-first centuries [Избавление от миражей: соцреализм сегодня].

The tractor appears in this film as a means of testing the value of the Soviet man. The youth who gains proficiency in operating a tractor becomes an adult Soviet citizen, mature, appreciated in society. Together with his proficiency in operating a tractor, he learns to make the right decisions and to become serious, principled, and solid. He is loved and admired both in his kolkhoz and in Soviet society as a whole. On the other hand, a young man who does not wish to gain such proficiency reveals by this his general worthlessness. Although he is physically mature, he is not mature spiritually. He is lightheaded, irresponsible, a liar, engaged in dubious schemes - one cannot trust him. In fact, he is taking a path to total failure in his life, and if he continues on that path it will finally lead him to prison and an early death. The only way for this weak adolescent to avoid this fate is for him to wake up and become serious, and the first step is to learn to operate a tractor.

To sum up, one can say that Soviet cinema was full of deliberate propaganda. What is surprising is the representation of work with a tractor as a decisive influence on a man's fate, and especially the representation of work with a tractor as an integral part of the "machismo" of the Soviet man.

\section{Список литературы}

Избавление от миражей: соцреализм сегодня / сост. Е. А. Добренко. М. : Сов. писатель, 1990. 413 с.

Соцреалистический канон / под ред. Х. Гюнтера, Е. Добренко. СПб. : Академ. проект, 2000. 1040 с.

${ }^{13}$ Yuri Gagarin (1934-1968), was a Soviet pilot and cosmonaut who became the first human to journey into outer space. Gagarin became an international celebrity and was awarded many medals and titles.

${ }^{14}$ Evgeny Yevtushenko (1932 (1933?)-2017) was a Russian poet, film producer, orator, and actor. He was one of the candidates for the Nobel prize in literature.

${ }^{15}$ Bella Akhmadulina (1937-2017) was a Soviet and Russian poet and short story writer. She was part of the Russian New Wave literary movement.

${ }^{16}$ Andrei Voznesensky (1933-2010) was a Soviet and Russian poet and writer. He was one of the "children of the " 60 s," the new wave of iconic Russian intellectuals resulting from the Khrushchev thaw.

${ }^{17}$ Mikhail Shemyakin (b. 1943) is a Russian painter, stage designer and sculptor. $\mathrm{He}$ is a controversial representative of the nonconformist art tradition of St Petersburg.

${ }^{18}$ Ernest Iosifovich Neizvestny (1925-2016) was a Russo-American sculptor, painter and graphic artist. He emigrated to the US in 1976 and lived and worked in New York City. 
Benjamin W. Work of Art in the Age of Its Technological Reproducibility: Second Version // Benjamin W. The Work of Art in the Age of Its Technological Reproducibility, and Other Writings on Media / ed. by M. W. Jennings, B. Doherty, T. Y. Levin. Cambridge, MA : Harvard Univ. Press, 2008. P. 19-55.

Cirlot J. E. A Dictionary of Symbols. $2^{\text {nd }}$ Ed. L. : Routledge, 1990. 514 p.

Cody T. The Propaganda Era: Film as a Political Tool // The Silhouette : [website]. 2013. Marth 28. URL: https://www.thesil.ca/the-propaganda-era-film-is-a-political-tool (mode of access: 24.03.2020).

Ellul J. Propaganda: The Formation of Men's Attitudes. N. Y. : Alfred A. Knopf, 1965. $320 \mathrm{p}$.

Fitzpatrich S. Everyday Stalinism: Ordinary Life in Extraordinary Times : Soviet Russia in the 1930s. Oxford : Oxford Univ. Press, 2000. 312 p.

Lapidus R. Passion, Humiliation, Revenge - Hatred in Man-Woman Relationships in the $19^{\text {th }}$ and $20^{\text {th }}$ Century Russian Novel. Lanham, Maryland : Lexington Books, 2008. $182 \mathrm{p}$.

Lerman Z., Kislev Y., Biton D. Agricultural Output and Productivity in the Former Soviet Republics // Economic Development and Cultural Change. Vol. 51. 2003. № 4. P. 999-1018. DOI 10.1086/376884.

Rezun M. Science, Technology, and Ecopolitics in the USSR. Westport, CT : Praeger, 1996. $228 \mathrm{p}$.

\section{References}

Benjamin, W. (2008). Work of Art in the Age of Its Technological Reproducibility: Second Version. In Benjamin, W. The Work of Art in the Age of Its Technological Reproducibility, and Other Writings on Media / ed. by M. W. Jennings, B. Doherty, T. Y. Levin. Cambridge, MA, Harvard Univ. Press, pp. 19-55.

Cirlot, J. E. (1990). A Dictionary of Symbols. $2^{\text {nd }}$ Ed. L., Routledge. 514 p.

Cody, T. (2013). The Propaganda Era: Film as a Political Tool. In The Silhouette [website]. Marth 28. URL: https://www.thesil.ca/the-propaganda-era-film-is-a-politicaltool (mode of access: 24.03.2020).

Dobrenko, E. A. (Ed.). (1990). Izbavlenie ot mirazhei: sotsrealizm segodnya [Deliverance from Illusions: Socialist Realism Today]. Moscow, Sovetskii pisatel'. 413 p.

Ellul, J. (1965). Propaganda: The Formation of Men's Attitudes. N. Y., Alfred A. Knopf. 320 p.

Fitzpatrich, S. (2000). Everyday Stalinism: Ordinary Life in Extraordinary Times : Soviet Russia in the 1930s. Oxford, Oxford Univ. Press. 312 p.

Günther, H., Dobrenko, E. (Eds.). (2000). Sotsrealisticheskii kanon [The Socialist Realist Canon]. St Petersburg, Akademicheskii proekt. 1040 p.

Lapidus, R. (2008). Passion, Humiliation, Revenge - Hatred in Man-Woman Relationships in the $19^{\text {th }}$ and $20^{\text {th }}$ Century Russian Novel. Lanham, Maryland, Lexington Books. 182 p.

Lerman, Z., Kislev Y., Biton D. (2003). Agricultural Output and Productivity in the Former Soviet Republics. In Economic Development and Cultural Change. Vol. 51. No. 4, pp. 999-1018. DOI 10.1086/376884.

Rezun, M. (1996). Science, Technology, and Ecopolitics in the USSR. Westport, CT, Praeger. 228 p. 
Illustration for the article:

Rina Lapidus. The "Erotic" Tractor in the Soviet Cinema

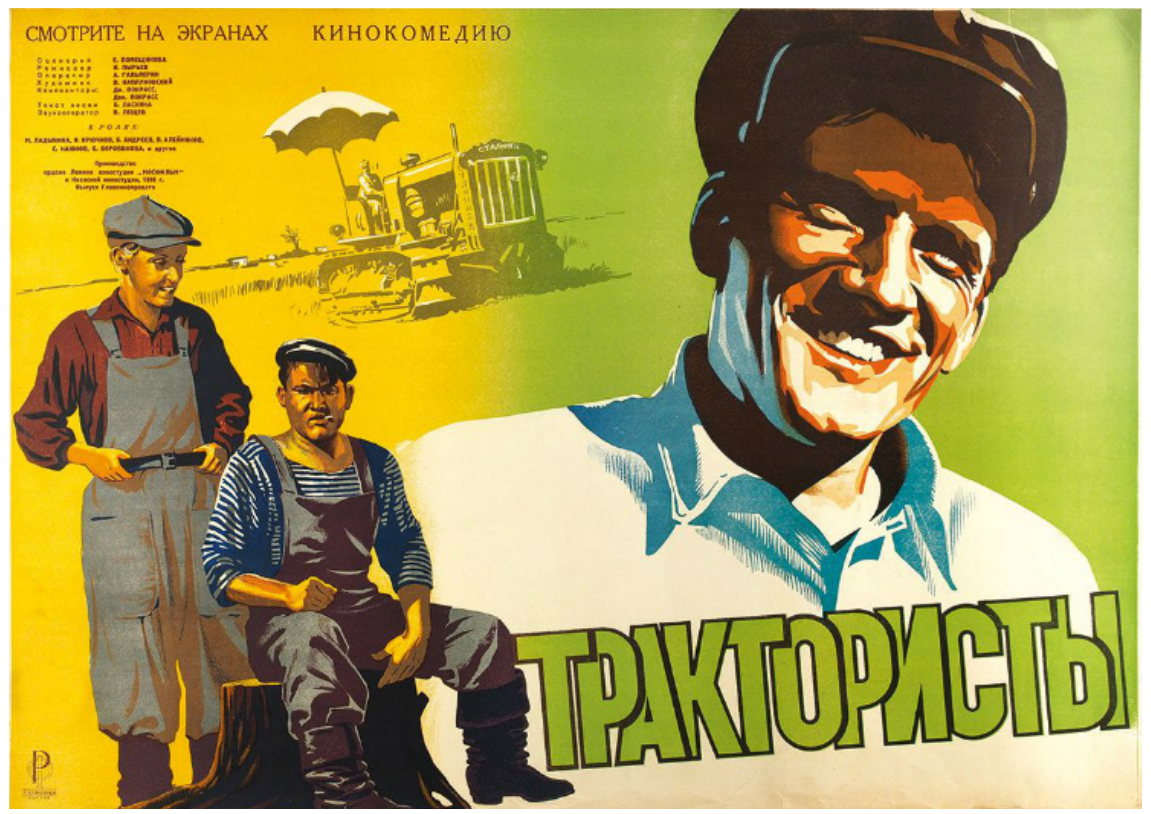

Poster for Tractor Drivers. 1949

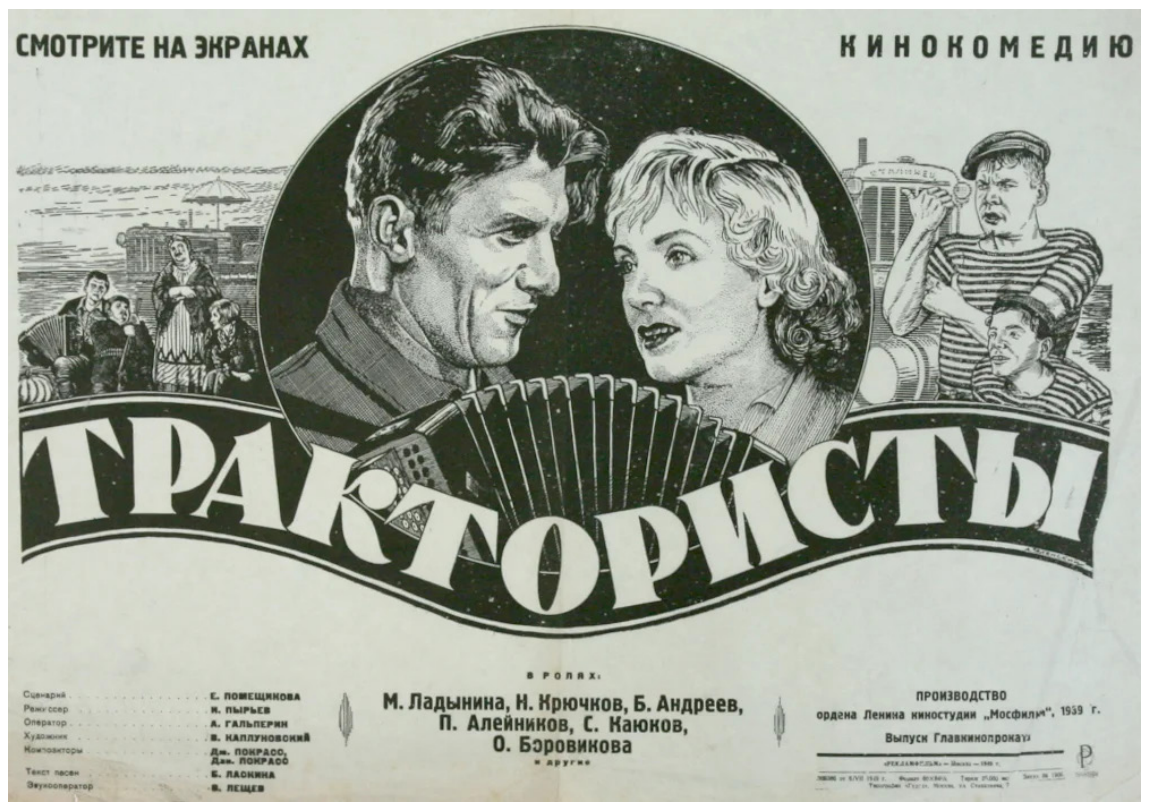

Poster for Tractor Drivers. 1940 